\title{
LEXICAL ENCAPSULATION AND EVALUATION IN PARLIAMENTARY DEBATE*
}

\section{ENCAPSULACIÓ LÈXICA I AVALUACIÓ EN EL DEBAT PARLAMENTARI}

\author{
JOSEP E. RIBERA \\ MARIA JoSEP MARÍN \\ Universitat de València \\ Departament de Filologia Catalana \\ josep.ribera@uv.es maria.j.marin@uv.es
}

Enviado: $27 / 05 / 2018$

Aceptado: 30/10/2018

\begin{abstract}
Lexical encapsulation consists of a series of abstract unspecific nouns (fact, plan...) referring to predicative antecedents. This study is based on a corpus of parliamentary debate in English, Catalan and Spanish (PD) and deals with encapsulation as a complex lexical cohesion device which allows the addressor to evaluate the information of the debates in various ways. Our work tries to highlight the role of lexical encapsulation to reflect the addressor's positioning with respect to the topic discussed, and to establish whether there are outstanding cross-linguistic differences. In order to delimit the diverse evaluative strategies, an approach from the perspective of prototype theory is adopted, since there are fuzzy boundaries among the different evaluative operations observed. Firstly, the distinction between implicit and
\end{abstract}

\begin{abstract}
Resum
L'encapsulació lèxica consisteix en una sèrie de noms abstractes i inespecífics (com fet, pla...) que es refereixen a antecedents predicatius. A partir d'un corpus de debat parlamentari (DP) en anglès, català i espanyol, aquest estudi s'ocupa de l'encapsulació com a mecanisme de cohesió lèxica complex que permet a l'emissor avaluar el contingut dels debats de diverses maneres. El nostre treball vol posar en relleu el paper d'aquest mecanisme cohesiu a l'hora de reflectir el posicionament de l'emissor respecte del tema tractat i observar si hi ha diferències contrastives. Per tal de delimitar les diverses estratègies avaluatives, adoptem una perspectiva basada en la teoria de prototipus, atès que els límits entre les operacions avaluatives observades són difusos. En primer lloc, diferenciem l'avaluació implícita de l'explícita i, a continuació, establim dues
\end{abstract}

\footnotetext{
* This research is part of the project Grampint (Grammar, Pragmatics and Multimodal Interaction, reference FFI2014-56258-P), funded by the Spanish Ministry of Economy and Competitiveness.

Para citar este artículo / To cite this article: Para citar este artículo / To cite this article: Ribera, Josep E. and Maria Josep Marín (2018). Lexical encapsulation and evaluation in parliamentary debate. ELUA, 32: 291-315. doi: 10.14198/ELUA2018.32.13
}

Enlace / Link: http://dx.doi.org/10.14198/ELUA2018.32.13 
explicit evaluation is established. As for explicit evaluation, two different operations are described: objectivizing and subjectivizing encapsulation. The objectivizing one works as a subtle strategy of persuasion addressed mostly to the opponents, whereas the subjectivizing encapsulating structures point to rally the unconditional allies. The results show similar trends in the three languages due to the homogenizing potential of $\mathrm{PD}$ as a distinct genre of political discourse.

KEYWORDS: encapsulation, lexical cohesion, objectivation, subjectivation, parliamentary debate. estratègies diferents en relació amb l'avaluació explícita: l'encapsulació objectivadora i l'encapsulació subjetivadora. La primera funciona com una estratègia de persuasió subtil adreçada sobretot als oponents, mentre que la segona cerca encoratjar els aliats incondicionals. Els resultats mostren tendències similars en les tres llengües, explicables perquè el DP és un gènere de discurs polític $\mathrm{amb}$ trets propis.

PARAULES CLAU: encapsulació, cohesió lèxica, objectivació, subjectivació, debat parlamentari.

\section{INTRODUCTION}

Parliamentary debate (henceforth PD) is a specific genre of political discourse within the general category of oral public discourse. Generally speaking, it consists in a ritualized interaction orally performed, but written-based, planned and formal (Cuenca 2014: 733). As a discourse which displays power dynamics, it is based on confrontation, but also on collaboration to meet a general common goal (Van Dijk 2000, Illie 2006, Cuenca 2014).

Van Dijk (2000) defines PD essentially through its context-based traits and highlights the fact that the only specific discourse features of PD are its argumentative intent and the topics being developed (Van Dijk 2000: 53). Illie (2006: 191) and Cuenca (2014: 733) underline PD's argumentative purpose more straightforwardly and make explicit the close relationship amongst evaluation, argumentation and persuasion in PD.

There are not many works in the literature which put into relation PD's nature as a discourse genre and lexico-grammatical and cohesive structures or word classes (Izquierdo Alegría and González Ruiz 2013b, Cuenca 2014). However, it appears that the hybrid nature between oral performance and written planning confers special cohesion features on PD. In fact, as a counterpart of its rhetorical design, PD tends to be explicitly organized by means of lexical cohesion markers (Halliday and Hasan 1976: 275-292, Ribera 2012), although scarce attention has been paid to it in the literature until now.

To fill in this gap, our study discusses the contribution of encapsulation as an outstanding lexical cohesion device (see Halliday and Hasan's 1976 concept of general nouns or Schmid's 2000 shell nouns) which delimits the argumentative structure of PD and its evaluative intents. On this account, this work sheds light on important questions with respect to the co-relation between PD as a genre and its discourse cohesive features. Specifically, this study shows that:

a) The high frequency of encapsulators proves to be an index of the informational density of PD.

b) The versatility of this cohesive device underlines in various ways the argumentative and evaluative nature of this genre of political discourse. 
In this respect, encapsulation emerges as a remarkable cohesive feature of PD due to its defining ability to refer to complex predicative chunks of textual information. Let us see an example (1).

(1) Well, it is about time that we got the facts on the record, which is what I will do with the time that I have left. It is preposterous to assert that an independent Scotland is not financially viable, as many members on the no side continue to do. As official data show,

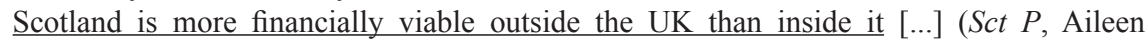
McLeod, SNP, 255)

In (1) the addressor uses the noun facts (encapsulator) to refer to the subsequent information (encapsulated content), in this case, to the rest of her speech. Thus, she ushers the topic of her immediately following discourse and packages it within the stable limits of a noun. In this way, she reifies the encapsulated content, i.e., recategorizes it as a thing (Langacker 1987: 183), which constitutes a signpost of the discourse structure and may act forwards as the object of subsequent anaphoric reference.

Furthermore, example (1) shows the ability of encapsulators to evaluate the encapsulated content: the noun facts introduces obviously as facts what is actually the MP's ostensive opinion, that "to assert that an independent Scotland is not financially viable" is "preposterous" and that "As official data show, Scotland is more financially viable outside the UK than inside it"; in other words, the encapsulator objectivizes what is indeed a subjective (or intersubjective, considering her political allies or voters) assertion on the addressor's part.

Thus, as shown in (1), through semantic reclassification of the encapsulated contents, encapsulators exhibit a high potential for evaluation, since they can be carriers of the addressor's point of view. On this last account, our study addresses encapsulation as a complex argumentative strategy which permits members of Parliament (MPs) to evaluate in various ways the information discussed in PD.

Our research analyzes encapsulation as a lexical cohesive device in three debates in English, Catalan and Spanish which took place in the Scottish, Catalan and Spanish Parliaments, respectively. Specifically, this work deals with the role of encapsulation as an evaluative device to reflect the addressor's positioning with respect to the topics discussed in the debates. Moreover, we try to establish whether there are outstanding cross-linguistic differences and similarities as for the discourse use of evaluative encapsulation in PD.

The results of this study show that encapsulation proves to be essential both to delineate the argumentative structure of PD as evaluative discourse and to enhance the interactive dynamics of parliamentary discussion. With regard to this, after close examination of the data, a cline from the most implicit type of evaluative operation, i.e., discourse structuring, to the most explicit one, i.e., the ostensive expression of the addressor's subjective stance, is established. In this way, three types of evaluative operations are determined as to the degree of implicitness / explicitness: a) structuring, an operation aimed at orienting the addressee's interpretation; b) objectivizing, with the purpose of presenting the information as common sense and appealing to consensus; c) subjectivizing, in order to exhibit an outstanding subjective opinion (Figure 1). 


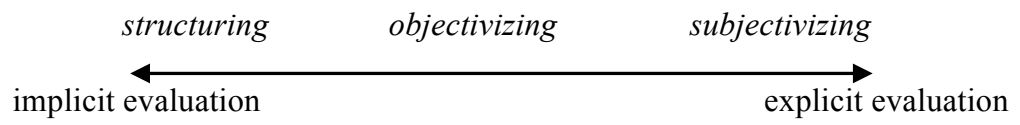

Figure 1. Cline of evaluative operations in PD.

The rest remainder of this study is structured as follows. Section 2 describes the theoretical framework. Section 3 is devoted to explaining the corpus and method of analysis. Section 4 offers firstly the general data drawn from the corpus $(\S 4.1)$; secondly, we discuss how the semantic reclassification performed by encapsulation works and in what way this semantic operation constrains the evaluative goals of PD ( $(4.2)$; thirdly, the difference between implicit and explicit evaluation is delimited ( $\$ 4.3$ ) and the (most) explicit evaluative operations of objectivizing ( $\S 4.4)$ and subjectivizing encapsulation ( $(4.5)$ are analyzed in detail. Finally, in section 5, the conclusions and some further research on the subject are underlined.

\section{THEORETICAL FRAMEWORK}

This study proceeds on the basis provided by some approaches to discourse analysis related to text linguistics (Halliday and Hasan 1976), functional grammar (Halliday 1994) and cognitive linguistics (Schmid 2000, 2018).

Our starting point is the concept of lexical cohesion as defined in Halliday and Hasan's (1976) seminal work as "the cohesive effect achieved by the selection of vocabulary" (Halliday and Hasan 1976: 275). In fact, with the concept of encapsulation, we adopt a restrictive interpretation of these authors' class of general nouns, derived basically from Schmid (2000) ${ }^{1}$.

Encapsulation is a lexical cohesion device defined by the ability to retrieve complex predicative chunks of textual information. Encapsulators or shell nouns, in Schmid's (2000) terminology, constitute a functional class of abstract and highly unspecific nouns which, due to their semantic nature, being abstract and unspecific, may refer to fragments of the previous or subsequent text, encompassing them within the shell of a noun. They are a functional class in the sense that they do not constitute a paradigmatic subset of nouns but are defined by their syntagmatic functioning in the development of discourse.

By means of their phoric cohesive textual function, encapsulators enhance the semantic characterization of the encapsulated information, while they contribute to the conceptual formation of discourse entities recategorized as nominals, that is, entities profiled as things in the mental representation of discourse, as shown in (2)

(2) They were partly about investing for the long term in an oil fund and partly about accelerated debt repayment. I do not think that, if we are to have an open and considered debate on these subjects, (Sct P, John Swinney, Cabinet Secretary, SNP, 223).

1 With respect to the diverse terminology and other theoretical aspects related to the definition of encapsulation within cohesive devices and, specifically, among referential devices and lexical cohesion, see Schmid (2000: 10-12, 2018: 109-128), Ribera (2012: 88-95), López Samaniego (2014: 33-36) and the literature discussed in these works. 
In (2) the noun subjects, together with the text deictic demonstrative these, retrieves anaphorically the set of previous activities which can match its semantic content: investing for the long term in an oil fund and accelerated debt repayment ${ }^{2}$. This cohesive strategy implies important semantic, discourse-pragmatic and cognitive consequences (Schmid 2000: 301-376; López Samaniego 2014: 39-53, 70-78):

a) As a noun, subjects has a stable lexical meaning which leads to the semantic characterization of the encapsulated content as "the thing that is being discussed, considered, or studied" (Cambridge English Dictionary).

b) The semantic non-specificity of the noun subjects makes it versatile enough to establish functional cohesive links with the activities previously introduced. In fact, as it can be observed in the dictionary definition, this non-specificity consists in a gap or lack of content in the semantic structure of the noun (what is being discussed, considered, or studied); thus, this gap has to be filled in or saturated by means of the encapsulated content. In other words, the meaning of subject puts into relation an activity of discussion and an object of discussion, which has to be specified through the previous discourse (Schmid 2000: 73-80).

c) The noun subjects recategorizes syntactically and cognitively as a noun the activities referred, i.e., it reifies these predicates and conceptualizes them as if they were things instead of relational entities (Langacker 1987: 189). In this way, the reified predicates constitute potential topics and can be referred to anaphorically from then onwards.

In sum, these three properties (semantic characterization, cohesive linking and recategorization or conceptualization power) locate encapsulators in a point of balance between full-content nouns —with high semantic potential for characterization, low cohesive ability and constant conceptualization power - and anaphoric pronouns - unable to conceptualize their antecedents or characterize them semantically, but prototypically cohesive units (Halliday and Hasan 1976: 275, Schmid 2000: 19).

Following Lyons's (1977: 442-445) orders of referential entities, who distinguishes concrete things $\left(1^{\text {st }}\right.$ order $)$ from events $\left(2^{\text {nd }}\right.$ order$)$ and abstract relations $\left(3^{\text {rd }}\right.$ order $)$, Schmid (2000: 87-91) defines six semantic classes or semantic uses of encapsulators ${ }^{3}:$ a) factual, b) linguistic, c) mental, d) modal, e) eventive and f) circumstantial ${ }^{4}$.

a) Factual (3rd order types), which represent abstract states of affairs and facts.

(3) As we heard earlier, the demographics are trickier in Scotland. Spending in Scotland is substantially higher already and the cost of borrowing, as we have heard time and again, is likely to be higher. For all those reasons, independence is extremely risky, which is why the better together campaign is being realistic (Sct P, Gavin Brown, Con, 433)

2 As for the frequent and narrow association of text deictic demonstratives with lexical encapsulation, see Ribera (2007: 162-165).

3 As opposed to extensional abstractness, Lyons's (1977: 442-445) order of referential entities involves intensional abstractness, a notion that offers a better insight into abstractness in terms of prototypes. Thus, events (2nd order entities) are more abstract than people and things (1st order) but less abstract than ideas or propositions (3rd order). 4 Flowerdew and Forest (2015: 29) establish a conceptually similar classification, though terminologically different. 
In (3) the whole NP based on the encapsulator reasons refers to the facts expressed by the previous sentences and relates them causally to the following information.

b) Linguistic (3rd order types), that denote utterances, i.e. linguistic activities, including propositional contents and illocutionary acts.

(4) a. North Ayrshire, which I represent, has a 6.8 per cent unemployment rate, which is the highest in Scotland, whereas that of Aberdeenshire is only 1.2 per cent, which is the lowest in Scotland. That is not only bad news for my constituents; (Sct P, Margaret McDougall, Lab, 305)

b. Where do Scots place their priorities? What makes them feel that they have what they need to live a decent life? What makes them feel that they can prosper as human beings? The Oxfam humankind index asked people those questions. (Sct P, Patrick Harvie, Green, 386)

The semantic content of the encapsulator in (4a) refers to the propositional content of the previous sentence and reclassifies it as news. The noun questions in (4b) retrieves obviously the successive previous questions formulated by the addressor, i.e. the interrogative illocutionary act.

c) Mental (3r order types), used to report ideas, opinions or cognitive states, as in (5).

(5) Stewart Stevenson has virtually proven the point that I am making, which is that the SNP views Scotland as some sort of colonial dependency. (Sct P, Ken Macintosh, Lab, 192)

d) Modal (3rd order types), which reflect the speaker's epistemic (6a), deontic (6b) or dynamic (6c) judgments on the encapsulated content ${ }^{5}$.

(6) a. The inconvenient truth, which even lifelong nationalists cannot hide from, is that Scotland's undoubted potential in renewable generation is strengthened by Scotland being part of a United Kingdom. (Sct P, Iain Gray, Lab, 332)

b. Section 30 of the Edinburgh agreement makes it amply clear that both Governments accept their obligation to respect the process and the will of the people. (Sct P, Alex Salmond, First Minister, SNP, 105)

c. why does the First Minister want Scotland to languish for another year and a half before we get the chance to vote on that? (Sct P, Johann Lamont, Lab, 24)

e) Eventive (2nd order types), which refer to events, i.e., activities ( + agentive, + dynamic), processes (- agentive, + dynamic) or states (- agentive, - dynamic).

5 Following Schmid (2000: 251), "dynamic modality is at work in combinations of nouns and infinitive clauses that are used to indicate what can possibly, probably or necessarily happen under certain circumstances".

6 The noun chance as in (6c) is considered a case of dynamic modality, i.e. indicating "what can possibly, probably or necessarily happen under certain circumstances (Schmid 2000: 251). Regarding dynamic modality, see Sentí (2017: 57-58) and the literature cited there. 
(7) Our efforts to promote and maintain that position are amplified by what we see around us, in the welfare cuts by a Tory-Liberal Government that we did not elect. (Sct P, Alex Salmond, First Minister, SNP, 36)

In (7) the noun efforts conceptualizes the activities "to promote and maintain that position", though the co-referential process needs to be explain by the metonymic relation between the efforts and their aims.

f) Circumstantial (2nd order types): referring to time, situations, locations where an event takes place or manners and conditions for doing things.

(8) We have kept clear of the European elections [...] so we have kept clear of having a double election [...] We have also kept clear of the huge major sporting events that Scotland is going to enjoy next year [...] For a decision of that importance, this is a proper, democratic and authoritative way to carry forward the argument. (Sct P, Alex Salmond, First Minister, SNP, 88)

In (8) the whole phrase including the encapsulator way focuses on the manner of performing the event singularized in the following to-clause ("to carry forward the argument") and then specified by the facts denoted by the previous sentences ("We have kept clear...").

Both encapsulators and shell contents can be semantically classified. According to Schmid (2000: 67), "it is [...] easier to decide on the conceptual status of shell nouns than on that of shell contents by means of simple semantic and conceptual analysis". The thing is that to determine the semantic status of the shell is compulsory to analyze the close discourse relation between these chunks of text and the corresponding shell nouns.

In fact, the fuzzy boundaries among the diverse classes are widespread and frequent. However, putting into relation the semantic entity of the encapsulator and that of the encapsulated content seems to be the best means to analyze and characterize how and under which constraints the evaluative operations emerge.

Moreover, because of the fuzzy boundaries among the semantic classes of encapsulators and those of the encapsulated contents, the limits between the diverse evaluative strategies are even fuzzier. Thus, an approach in terms of prototypes theory (Geeraerts 2006) is given to offer an accurate description of the data.

\section{CORPUS AND ANALYTIC METHOD}

Our corpus consists of three debates in three languages:

a) Catalan (Investiture): the Plenary Session of Investiture of the President of the Government of Catalonia, the Generalitat de Catalunya, which took place on December, $20^{\text {th }}$ and $21^{\text {th }}, 2012$ in the Parliament of Catalonia.

b) Spanish (Congreso): the Plenary Session held to take into account the Proposition of the Parliament of Catalonia to delegate to the Government of Catalonia powers to authorize, call and celebrate a referendum on the political future of Catalonia. This took place on April, $8^{\text {th }}, 2014$, in the Congreso de los Diputados of the Spanish Parliament. 
c) English $(\operatorname{Sct} P)$ : the Statement by Alex Salmond on Scotland's Independence Referendum and the Debate on the motion of the SNP John Swinney on Scotland's financial strength. These took place on March, 21 $1^{\text {st }}, 2013$ in The Scottish Parliament.

The debates within our corpus share the general discussion topic, i.e. the independence of Catalonia and Scotland. The selection of the debates with respect to the topic is due to two reasons:

a) As we are analyzing a cohesive device that implies semantic conceptualization and cognitive recategorization, variables that could be attributed to the subject of the debates should be controlled.

b) The issues of the independence of Catalonia and Scotland generate polarized political points of view in the respective parliaments involved.

In the case of the debates in Catalan and Spanish, we have chosen plenary sessions and have only analyzed the first intervention of the spokesperson of each political group. Thus, we have not taken into account the potential replication turns conceded to the opposition speakers, in order to restrict the monological / dialogical different type of discourse performed. As for the debate in The Scottish Parliament, the procedure that is more similar to the plenary sessions of the Catalan and Spanish parliaments are the so-called ministerial statements and motions (see Scottish Parliamentary Corporate Body, 2013: 9; Standing Order of the Scottish Parliament, 2015 chapter 13, rule 13.1).

On this account, a substantial difference between the debates in Catalan and Spanish, on one side, and the British parliamentary tradition, on the other, must be underlined. PDs in the Hispanic world are structured on the basis of a series of speeches of the representatives of the various parliamentary groups, speaking in turn in accordance with the number of seats won at the polls. And there is no possibility of interrupting or questioning the MP in medias res; in fact, these interventions work in discourse as a series of successive monologues.

In contrast with this Hispanic parliamentary dynamics, in the British tradition, the discussion that follows a ministerial statement or a deputy motion is rather much dialogical: despite the planning underlying the MPs interventions, s/he can be interrupted, by asking him or her to give way. And the addressor has the option of giving the way or not.

As for the analytical method, firstly the encapsulators and the encapsulated contents in the debates have been identified manually according to their three defining criteria:

a) The abstractness and semantic (un)specificity of the potential encapsulators.

b) Their cohesive phoric nature.

c) The predicative nature of the encapsulated information? ${ }^{7}$.

7 It is difficult, if not impossible, to automatize the identification of all the encapsulators through the lexicogrammatical patterns in which they occur. Although most of them appear in some closed patterns (e.g. $N$-clause, th- $N, N$ be-clause, clause-be- $N$ ), the decision on their abstractness, unspecificity and phoric nature can only rely on close semantic and discourse analysis of each potential candidate. Even more difficult is to find out whether an abstract unspecific noun retrieves a predicative antecedent or, conversely, acts as a mere hypernym of other entities already profiled as "things" by NPs. 
Secondly, both the encapsulators and the encapsulated contents have been classified, considering the six-fold semantic categorization proposed by Schmid (2000). Thirdly, the explicitly evaluative encapsulators have been identified on the basis of their attitudinal and/or modal meaning, since these are semantic traits privileged to carry out evaluative functions. A number of other constraints, such as the encapsulators' co-occurrence with demonstrative determiners, adjective complements and emphatic syntactic structures have also been considered. The results of our analysis are reported in section 4 .

\section{ANALYTICAL RESULTS}

In this section, firstly, the general data of the encapsulators drawn from our corpus are tackled. Secondly, the semantic classes of both the encapsulators and the encapsulated contents are quantitatively discussed. Following this, the gradient difference between implicit and explicit evaluation is considered. Finally, the objectivizing and subjectivizing evaluative operations are analyzed considering the prototypical and less prototypical instances.

\subsection{General data}

The general data regarding the encapsulators in each language are as follows (see Table 1 and Graphic 1).

\begin{tabular}{lccc}
\hline & English & Catalan & Spanish \\
\hline N encapsulators & 472 & 465 & 480 \\
N total words & 29,507 & 41,625 & 50,854 \\
\hline Relative frequency of encapsulators (\%) & 1.5996 & 1.171 & 0.9439 \\
\hline
\end{tabular}

Table 1.General data of the encapsuladors in PD

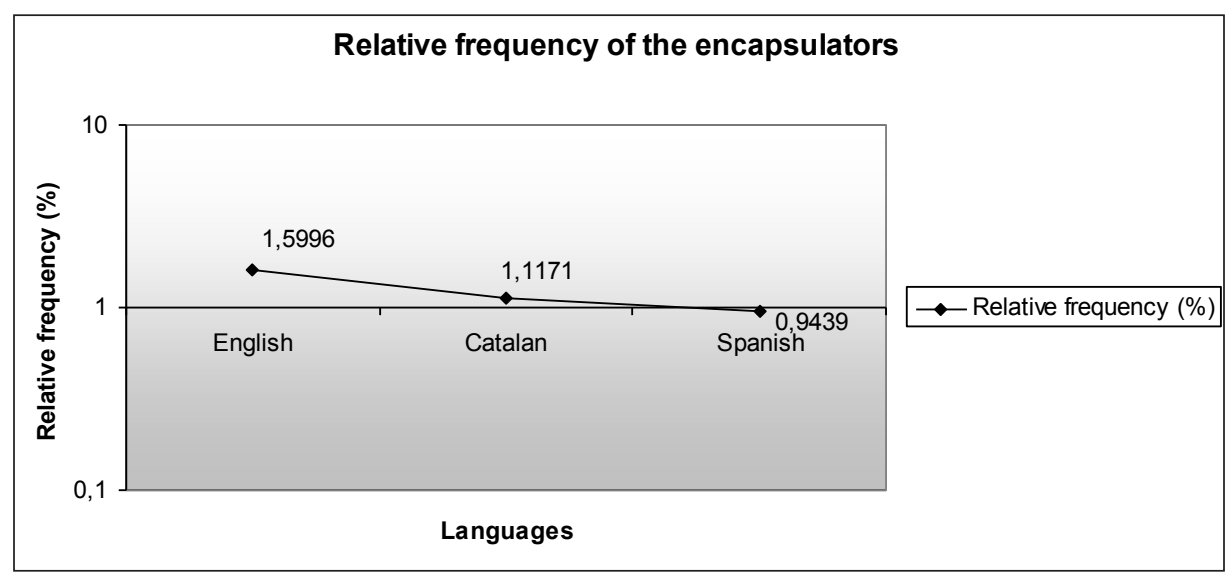

Graphic 1. Relative frequency of the encapsulators in PD 
The data in Table 1 and Graphic 1 show an important first result: the relative frequency of encapsulators is higher in English than in Catalan and Spanish.

The statistical tests show that there is a significant association between the languages and the frequency of encapsulation $\left(\chi^{2}(2)=71.023, p<0.001\right)$. However, the effect size when comparing the three languages is small (Cramer's $\mathrm{V}=0.024)$, as expected, otherwise, since the differences in percentage are meager with respect to the samples' wide extension in words.

The statistical results are also significant when the languages are compared two by two: English vs. Catalan $\left(\chi^{2}(1)=30.924, p<0.001\right.$, Cramer's V $\left.=0.021\right)$; English vs. Spanish $\left(\chi^{2}(1)=68.589, p<0.001\right.$, Cramer's V = 0.029); Catalan vs. Spanish $\left(\chi^{2}(1)=6.792, p\right.$ $=0.009$, Cramer's V $=0.009)$. As can be observed, the smallest effect is obtained when comparing Catalan and Spanish, which may suggest that, given the stylistic similarity and phylogenetic identity between the two languages, the difference could be hardly significant or even negligible in a different corpus.

Finally, the comparison between English, on the one hand, and Catalan and Spanish pooled together, on the other, also reveals a significant association with an almost identical result to that obtained in the comparison of the three languages separately $\left(\chi^{2}(1)=65.040\right.$, $p<0.001$, Cramer's $\mathrm{V}=0.023$ ).

So the Scottish debate shows a higher encapsulating density in comparison to the Catalan and the Spanish ones, at least in our corpus. Conversely, the differences between the latter, although statistically significant, are smaller and should be supported by further research.

It may be assumed easily that encapsulators' density is an index of cohesion degree (see the notion of cohesive vs. segmented style, in Serafini 1992 and Cuenca 2000) and information density (Jansen 2003; Borreguero 2006; Ribera 2016), considering encapsulators' potential for informational condensation. Thus, PD proves to be an informationally dense genre, or at least more dense than other genres, such as journalistic opinion editorials (López Samaniego 2014) ${ }^{8}$.

\subsection{Semantic classes of the encapsulators and the encapsulated contents in PD}

The diverse semantic classes of the encapsulators are shown in Table 2 and Graphic 2. As Table 2 and Graphic 2 show, the debates in the three languages exhibit rather similar general tendencies as for the semantic classes of the encapsulators, a fact that can be attributed to the homogenizing power of the discourse genre. Firstly, there is a high degree of coincidence between the debates in English and Catalan: the mental, linguistic, modal and factual nouns, in this order, are the preferred choices, with converging relative frequencies in the case of linguistic and mental encapsulators. The debate in Spanish shows a slight contrast with respect to the Scottish and Catalan ones, since modal and factual encapsulators are more frequent than linguistic ones.

8 The relative frequency of the encapsulators in López Samaniego's (2014) corpus of editorials is $0.6 \%$ (54.546 words; 326 encapsulators); therefore, lower than ours. 


\begin{tabular}{|l|r|r|r|r|r|r|}
\hline \multirow{2}{*}{ Language / Classes } & \multicolumn{2}{|c|}{ English } & \multicolumn{2}{c|}{ Catalan } & \multicolumn{2}{|c|}{ Spanish } \\
\cline { 2 - 7 } & $\mathbf{N}$ & $\mathbf{\%}$ & $\mathbf{N}$ & $\mathbf{\%}$ & $\mathbf{N}$ & $\mathbf{\%}$ \\
\hline factual & 82 & 17.4 & 69 & 14.8 & 99 & 20.6 \\
\hline linguistic & 112 & 23.7 & 110 & 23.7 & 90 & 18.8 \\
\hline mental & 154 & 32.6 & 151 & 32.5 & 128 & 26.7 \\
\hline modal & 95 & 20.1 & 83 & 17.8 & 122 & 25.4 \\
\hline eventive & 15 & 3.2 & 34 & 7.3 & 28 & 5.8 \\
\hline circumstantial & 14 & 3 & 18 & 3.9 & 13 & 2.7 \\
\hline Total & $\mathbf{4 7 2}$ & $\mathbf{1 0 0}$ & $\mathbf{4 6 5}$ & $\mathbf{1 0 0}$ & $\mathbf{4 8 0}$ & $\mathbf{1 0 0}$ \\
\hline
\end{tabular}

Table 2. Semantic classes of the encapsulators in PD

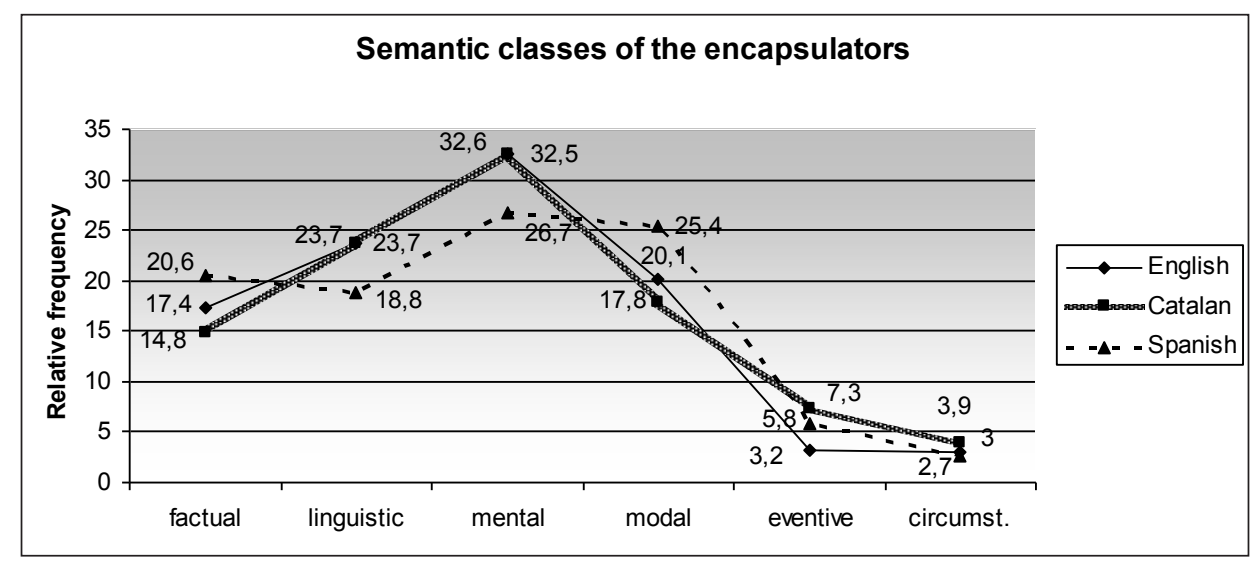

Graphic 2. Semantic classes of the encapsulators in PD

A detailed analysis of these results exceeds the limits of the present work and must now be postponed for further research. However, the higher (coincident) frequencies of linguistic encapsulators in the Scottish and Catalan debates should be related to their being more explicitly structured than the Spanish one, since linguistic encapsulators work mainly as discourse organizers, as shown in (9).

(9) [...] faré el resum de: mà estesa per a l'autodeterminació d'aquest poble, mà estesa amb el nostre poble, avançarem on sigui per avançar. (Investiture Debate, CUP, Fernàndez, 406) [...] I will provide the [following] summary: outstretched hand for this people self-determination, outstretched hand with our people, we will go ahead wherever necessary to go ahead [in this process]

As stated before, the comparison between the semantic content of the encapsulators and that of the encapsulated contents offers important information regarding the evaluative operations which take place in the debates. In this respect, it should be hypothesized that semantic identity between encapsulated content and encapsulator may imply conceptual maintenance and low potential for overt evaluation, as in (10). 
(10) Y quiero además hacerlo reconociendo el mismo hecho de que estén aquí, de que vengan aquí a defender sus ideas y a exponer sus argumentos desde la tribuna (Congreso, PP, Alonso, 456)

I would like to do it [welcome the Catalan representatives] by acknowledging the very fact that you (politeness) are here, that you (politeness) come here to defend your (politeness) ideas and to expose your (politeness) arguments from the rostrum

The encapsulator hecho (fact) in (10) refers factually to information that is indeed an objective fact: "que estén aquí, de que vengan aquí a defender sus ideas y a exponer sus argumentos desde la tribuna". Thus, no explicit evaluative operation is at work; however, the encapsulator aims at guiding and orienting the addressees' interpretation by means of rendering the "averred alignment" of the encapsulated propositional content with the world. This is consistent with Hunston's (2000) concept of "evaluation of status" and Yamasaki's (2008) "implicit evaluation" (see $\S 4.3$ ).

Conversely, when an encapsulator reclassifies semantically the encapsulated content, its potential for explicit evaluation increases, as in (11):

(11) $[\ldots]$ they entirely support my view that Scotland's strength lies in our being part of the UK. (Sct P, Ken Macintosh, Lab, 195)

The noun strength in (11) offers the addressor's viewpoint of what is an objective fact, i.e., that Scotland is part of the UK. Therefore, this fact is evaluated axiologically by means of the encapsulator, which highlights the speaker's subjective judgment that being part of the UK is positive for Scotland.

Table 3 shows the data drawn from the semantic classification of the encapsulated contents matched with the encapsulators of our corpus 9 . These data are compared to the semantic classes of the encapsulators in each language in Graphic 3 for English, Graphic 4 for Catalan and Graphic 5 for Spanish.

\begin{tabular}{|l|r|r|r|r|r|r|}
\hline \multirow{2}{*}{ Language } & \multicolumn{2}{|c|}{ English } & \multicolumn{2}{c|}{ Catalan } & \multicolumn{2}{c|}{ Spanish } \\
\cline { 2 - 7 } & $\mathbf{N}$ & $\mathbf{\%}$ & $\mathbf{N}$ & $\mathbf{\%}$ & $\mathbf{N}$ & $\mathbf{\%}$ \\
\hline factual & 56 & 11.9 & 91 & 19.6 & 59 & 12.3 \\
\hline linguistic & 100 & 21.2 & 77 & 16.5 & 74 & 15.4 \\
\hline mental & 186 & 39.4 & 165 & 35.5 & 117 & 24.4 \\
\hline modal & 15 & 3.2 & 14 & 3.0 & 29 & 6.0 \\
\hline eventive & 115 & 24.3 & 118 & 25.4 & 201 & 41.9 \\
\hline circumstantial & 0 & 0.0 & 0 & 0.0 & 0 & 0.0 \\
\hline Total & $\mathbf{4 7 2}$ & $\mathbf{1 0 0}$ & $\mathbf{4 6 5}$ & $\mathbf{1 0 0}$ & $\mathbf{4 8 0}$ & $\mathbf{1 0 0}$ \\
\hline
\end{tabular}

Table 3. Semantic classes of the encapsulated content in PD

9 We are aware of the difficulties to categorize the various semantic types of encapsulated contents and to count their relative frequencies, considering that, by definition, "contents" are conceptual, and thus do not "occur" in texts as encapsulators. However, an attempt to do it may be offered attending to the semantic-pragmatic dynamic relation established between the encapsulator and the encapsulated content (cfr. Schmid, 2000: 70-81, for the concept of stylistic abstractness). 


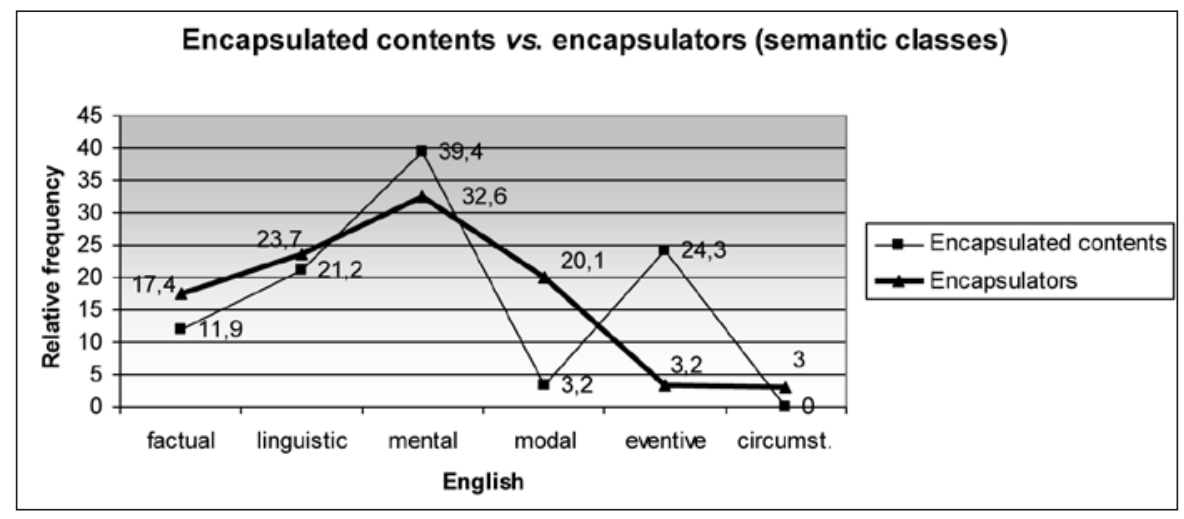

Graphic 3. Encapsulated contents vs. encapsulators in PD (English)

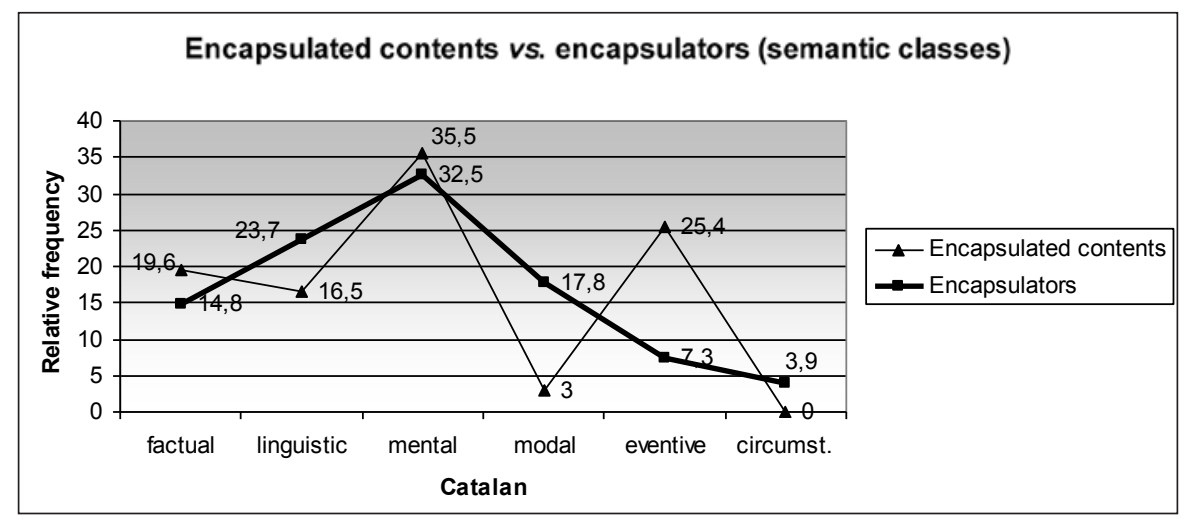

Graphic 4. Encapsulated contents vs. encapsulators in PD (Catalan)

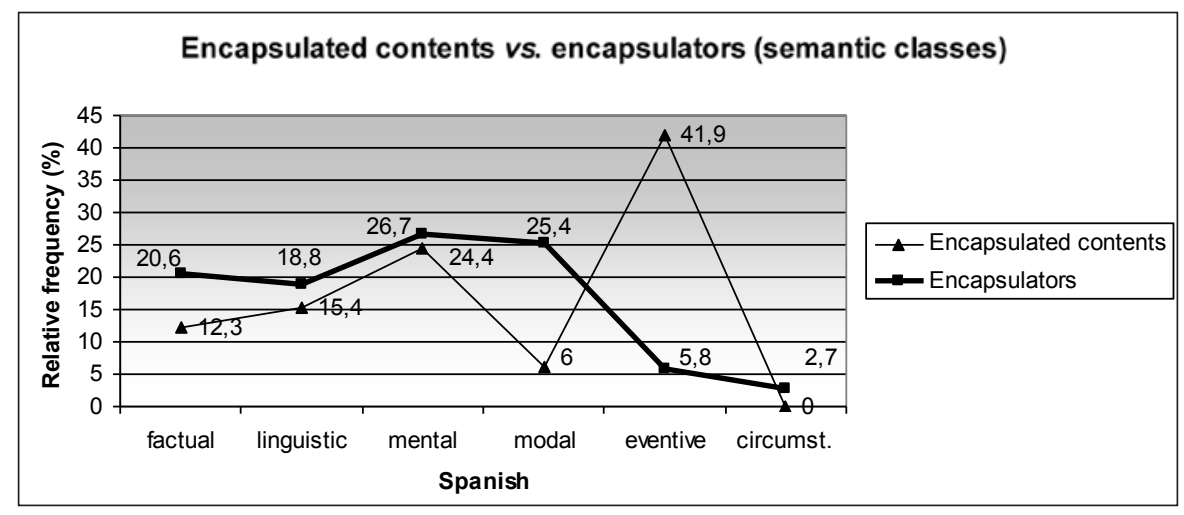

Graphic 5. Encapsulated contents vs. encapsulators in PD (Spanish) 
The comparison between the relative frequencies of the semantic classes of the encapsulated contents and those of the encapsulators in each language, shown in the previous graphics, exhibits three noteworthy cross-linguistic results:

a) The semantic reclassifying operations concerning the factual, linguistic and mental encapsulators in our corpus are less frequent in the three languages and quite coincident in English and Catalan. The differences between the relative frequencies of the encapsulated contents and the encapsulators in these three semantic classes do not exceed 8.5 percentage points.

b) The frequencies of the modal encapsulated contents are low with respect to the other semantic classes. However, the frequencies of modal encapsulators are higher in the three languages ${ }^{10}$. They differ 16.9 percentage points in English, 14.8 in Catalan and 19.4 in Spanish.

c) Conversely, the frequencies of eventive contents are remarkably high, whereas eventive encapsulators are much lower in the three languages ${ }^{11}$. They differ 21.1 percentage points in English, 18.1 in Catalan and 36.1 in Spanish.

These results lead us to hypothesize that most evaluative operations involve modal encapsulators that reconceptualize facts, linguistic utterances, judgments and (future) events from the addressor's viewpoint, inner and volitive in (12a), and events reclassified as facts, judgments or mere linguistic activities (12b).

(12) a. Does the First Minister agree that independence offers us the opportunity to assume our rightful place in the world? (Sct P, Chic Brodie, SNP, 114)

b. if leaving the United Kingdom is the key to Scotland's prosperity, why does the First Minister want Scotland to languish for another year and a half? (Sct P, Johann Lamont Lab, 25)

In (12a), the modal dynamic encapsulator evaluates positively the speaker's subjective volitive judgment ("to assume our rightful place in the world"), which is shown as an objective opportunity for Scotland. In (12b), a future hypothetical event ("leaving the United Kingdom") is judged as essential "to Scotland's prosperity" by the mental encapsulator key, which, moreover, has a certain modal meaning as well.

Both examples give support to the hypothesis explained just above. However, discourse reality is far from being as straightforward as these data and this hypothesis seem to imply. This point will be discussed in the following sections.

10 Obviously, the point is not that there are few epistemic and deontic contents, but that it is easier to classify them as opinions and judgments or even events introduced with a certain modal tinge, as in (i), where the epistemic probability conferred by the modal verb would does not prevent interpreting Salmond's words as his own opinion or desire, and, thus, as a mental encapsulated content.

(i) people would have the appetite to move on to the equality that an independent Parliament will provide. There is every basis to believe that that is the positive argument that will carry this country. (Sct $P$, Alex Salmond, First Minister, SNP).

11 There is no encapsulated content classified as circumstantial because this semantic class is not defined for encapsulated contents, but only for nouns focusing on a circumstantial aspect of an encapsulated event. 


\subsection{Degrees of implicitness / explicitness of the evaluative operations by means of encapsulation}

Díez Prados and Cabrejas Peñuelas (2012) consider that some potential evaluative persuasive function is somehow inherent in cohesive devices, since they "produce an intrinsic effect of repeating and, thus, insisting, on the main issues stated in the text" and "can potentially fulfill an echoic function, creating a resonance of form and content through the text" (Díez Prados and Cabrejas Peñuelas 2012: 39).

According to this, the operation of recategorizing the encapsulated contents performed by encapsulators constitutes in itself a strategy aiming at evaluating the information. Thus, the reifying nature of this lexical cohesion device activates its powerful structuring ability (Marín and Ribera 2018): each encapsulator signposts the corresponding discourse chunk, which can thus be referred to as a topic in the subsequent text, as shown in (13).

(13) Ruth Davidson's argument that independence is a departure from the progress of national self-determination does not hold water when it is examined. (Sct P, Alex Salmond, First Minister, SNP, 47)

The linguistic noun argument in (13) encapsulates the content of the that-clause, which is afterwards retrieved as a topic by the pronoun it in the embedded wh-clause ("when it is examined") $)^{12}$. In this way, the encapsulator contributes to make explicit the discourse structure ${ }^{13}$.

In this regard, the inherent structuring function of encapsulators performs the most implicit evaluative operation, since they aim at guiding the addressee's apprehension of the previous or following information by labeling it.

In fact, following Yamasaki (2008: 80), encapsulators constrain the addressee to interpret the encapsulated content in the sense that they provide "a frame of reference with which to interpret new information" and "the addressee is presented with no options but is instead positioned to accept the way the label packages its contextual meaning and renews the already-constructed discourse entity".

On the other hand, according to Hunston's (2008) concept of "evaluation of status", encapsulators highlight "the averred nature or degree of alignment, or correspondence, between a proposition and the world". Let us see how our concept of implicit evaluation works with regard to Yamasaki's (2008) and Hunston's (2008).

(14) $[\ldots]$ due to volatility and the fact that reserves are diminishing, we face serious challenges in the medium to long term. (Sct P, Gavin Brown, Con, 214)

In (14), the encapsulator constrains the addressee to assume as an indisputable given fact that "reserves are diminishing". Therefore, the encapsulated content is evaluated as certainly aligned with the world. It doesn't matter whether it is true or not; and there is not any discourse cue that may allow the addressee to think that he or she is dealing with the addressor's opinion: what is highlighted is the status of the propositional content with respect to the real world.

12 Obviously, we are conscious that other referential intrepretations are possible.

13 In fact, encapsulation makes clear the development of the discourse information structure (Ribera 2016). In this respect, the lexico-grammatical and discourse patterns in which the encapsulators occur play an important role but this topic is beyond the limits of this study. See Schmid (2000: 21-27), López Samaniego (2014: 189-265) and Ribera (2016). 
Besides this afore shown intrinsic structuring most implicit evaluative function of encapsulators, some of them involve more explicit evaluative operations.

(15) a. [...] the truth is that Alex Salmond knows that if he held the referendum now he would not just lose it, he would be routed. (Sct P, Johann Lamont, Lab, 29)

b. Yesterday's budget statement coincided with a growth forecast of only 0.6 per cent for this year. Back in June 2010, the chancellor forecast growth of 2.9 per centnearly five times higher than what is now forecast. That is a damning judgment on the UK Government's record on the economy. (Sct P, John Swinney, Cabinet Secretary, SNP, 164)

The modal epistemic encapsulator truth in (15a) reclassifies as an objective fact what is no more than Johann Lamont's wish for Salmond's political future, i.e., it objectivizes a subjective idea as a fact. Conversely, the mental noun judgment in (15b) subjectivizes the objective information expressed by the shell content; the subjectivizing operation is due to both the encapsulator and the negative evaluative adjective damning.

The results concerning the three evaluative operations in our corpus are shown in Table 4 and Graphic 7.

\begin{tabular}{|l|r|r|r|r|r|r|}
\hline \multirow{2}{*}{$\begin{array}{l}\text { Language / } \\
\text { Evaluative operations }\end{array}$} & \multicolumn{2}{|c|}{ English } & \multicolumn{2}{|c|}{ Catalan } & \multicolumn{2}{|c|}{ Spanish } \\
\cline { 2 - 7 } & $\mathbf{N}$ & $\mathbf{\%}$ & $\mathbf{N}$ & $\mathbf{\%}$ & $\mathbf{N}$ & $\mathbf{\%}$ \\
\hline structuring & 96 & 20.3 & 147 & 31.6 & 88 & 18.3 \\
\hline objectivizing & 254 & 53.8 & 218 & 46.9 & 264 & 55.0 \\
\hline subjectivizing & 117 & 24.8 & 81 & 17.4 & 94 & 19.6 \\
\hline other & 5 & 1.1 & 19 & 4.1 & 34 & 7.1 \\
\hline Total & $\mathbf{4 7 2}$ & $\mathbf{1 0 0}$ & $\mathbf{4 6 5}$ & $\mathbf{1 0 0}$ & $\mathbf{4 8 0}$ & $\mathbf{1 0 0}$ \\
\hline
\end{tabular}

Table 4. Evaluative operations of the encapsulators in PD

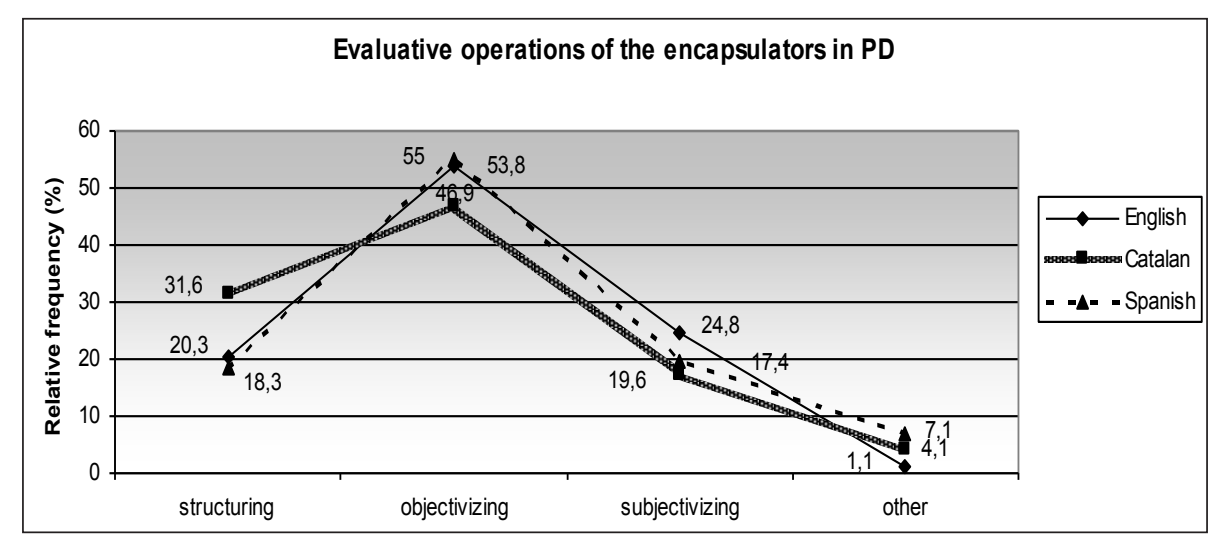

Graphic 7. Evaluative operations of the encapsulators in PD 
Table 4 and Graphic 7 show that the objectivizing function is by far the preferred evaluative operation in the three languages. In English, the subjectivizing and structuring operations show similar relative frequencies, although the former is a little bit higher. In this respect, the Spanish debate is more similar to the Scottish one, with the frequency of subjectivizing encapsulators fairly close to the structuring ones. Finally, the structuring encapsulators are rather more frequent in the Catalan debate.

These discourse evaluative operations of the encapsulators can be explained in terms of Halliday's (1994) textual and interpersonal metafunctions. The structuring cohesive force is linked to the former, while the objectivizing and subjectivizing evaluative operations are related to the latter, since more explicit evaluation tries to guide openly the addressee's interpretation (Izquierdo Alegría and González Ruiz 2013b: 190; Mur Dueñas 2003-2004: 138). This gives evidence to support the idea that "cohesion itself is an interpersonal as well as textual phenomenon" (Thompson and Zhou 2000: 122).

\subsection{Objectivizing evaluation}

Objectivizing encapsulation is characterized by the fact that it is a subtle, somehow little explicit, strategy, usual in political discourse, to evaluate the encapsulated information by appealing to consensus, to what is assumed to be common sense or the majority's opinion or will. As Fuentes Rodríguez (2010: 9) puts it, encapsulators (or discourse labels, as she names them) "se pueden erigir en estrategias eficaces de argumentación implícita, toda vez que el filtro interpretativo o las valoraciones del emisor se presentan [...] como presupuestas, como indiscutibles, en fin, como atribuidas a una voz colectiva, no a la voz subjetiva del emisor político".

Not every instance of objectivizing evaluative encapsulation seems to derive straight from the relation between a subjective encapsulated content and an axiologically neutral encapsulator. For analytical purposes, a distinction has to be drawn between prototypical and non-prototypical instances.

\subsubsection{Prototypical objectivizing encapsulation}

Prototypical objectivizing encapsulation is observed in those instances where subjective contents, i.e., opinions and judgments, are reclassified as objective facts and events.

(16) Jo no parlaré del fet que vostè és deslleial amb els ajuntaments; (Investiture, SànchezCamacho, PP, 249)

I am not to talk about the fact that you are disloyal to local councils

In example (16) the representative of the Partido Popular in the Catalan Parliament accuses Artur Mas, the candidate for President of the Generalitat de Catalunya in the 2012 election, of being disloyal to local councils; obviously, that is her own opinion, but it is objectivized as a fact.

(17) Venimos hoy a hablar aquí, a proponerlo con la mayor y la mejor de las voluntades, pero también con la mayor determinación para hacer posible que las catalanas y los catalanes sean consultados. (Congreso, Turull, Catalan Parliament representative, CiU, 7) 
We are coming today to talk here, to propose it [the referendum] with the greatest and the best wills, but also with the greatest determination to make it possible that Catalan women and men be consulted

Similarly, in (17) the representative of the Catalan Parliament, sent to the Spanish Congreso de los Diputados to promote a referendum for Catalonia's self-determination, considers that his desire for a referendum (to make it possible that Catalan women and men be consulted) is requested with the greatest and the best wills, but also with a determination. In this way, he underlines his appealing to achieve an agreement (otherwise, with an straightforward determination) which is rejected by the opponents.

Example (17) shows that the evaluative operation does not depend only on the semantic reclassification of the encapsulated content (Izquierdo Alegría and González Ruiz 2013a), since both the content and the encapsulator in (17) are mental: they express ideas or objects of thought. However, the positive volitional attitudinal meaning of the noun voluntades (wills) and the premodifiers la mayor y la mejor (the greatest and the best) are intended to show the addressor's stance of outstretched hand and good will towards the opponents, thus objectivizing what is in fact a subjective wish by appealing to consensus building. However, adding the encapsulator determination puts forward explicitly the adressor's stance as well. In fact, example (17) falls within the fuzzy boundaries between prototypical and non-prototypical objectivizing encapsulation, together with a rather deontic alternative expressed as an indirect illocutionary act (the greatest determination of the representative of the Catalan Parliament is not under discussion).

\subsubsection{Non-prototypical objectivizing encapsulation}

As advanced in (17), the objectivizing evaluative operation is often not (only) performed by the encapsulator itself. In fact, other syntactic and discourse-pragmatic constraints which enhance the addressor's intention to appeal to common sense and consensus have to be taken into account in this regard, considering the role of a) specifiers, b) adjectival or prepositional modifiers, and c) predicates and some syntactic patterns.

a) The specifiers' constraint: this consists mainly in the use of first person plural possessives that include the MP as part of a group or the whole community.

(18) Sabem -ho sabem- que som ambiciosos, però també aquest és el nostre deure respecte al conjunt dels nostres ciutadans. (Investiture, ERC, Junqueras, 169)

We know -we do know it-that we are ambitious, but this is also our duty towards our citizens as a whole.

In (18), the objectivizing evaluation of the addressor's judgment works not only by means of the modal deontic noun deure (duty). In spite of the fact that this noun may constitute by definition a subjective understanding of a moral value, the addressor assumes that his stance is the one expected in any politician by the majority. Thus, the first occurrence of the $1^{\text {st }}$ person plural possessive nostre (our) activates the reference to an indefinite global addressor, who may be the members of ERC, the Catalan left-wing pro- 
independence political party, all the MPs or all the citizens; the second one (els nostres ciutadans), however, reinforces the addressor's objectivizing intents by appealing straight to the whole set of Catalan citizens.

b) The constraint of adjectival or prepositional modifiers: the use of certain modifiers intends to communicate that the addressor's stance is shared by the whole community.

(19) [...] dudo que exista mejor forma de servir a mi país que defender hoy aquí este proyecto de futuro. (Congreso, Rubalcaba, PSOE, 236)

[...] I don't believe that there is a better way to serve my country than defending here and now this project for the future.

In (19), the encapsulator forma (way) is semantically neutral and consistent with the objective encapsulated content; however, the prepositional postmodifier de servir a mi pais (to serve my country) enhances even more the objectivizing evaluation of the encapsulated event by presenting it as an act on behalf of the whole country.

c) The constraint of predicates and syntactic structures: the semantics of some predicates and syntactic structures also enhance the objectivizing evaluation.

(20) I welcome the work that the Scottish Government has undertaken to date to inform voters about the process that would follow a yes vote, following the recommendations of the Electoral Commission. (Sct P, Roderick Campbell, SNP, 103)

In (20), the noun work, which is already objectivizing by its own neutral semantic content, is strengthened by the commissive meaning of the predicate has undertaken. In this case, the encapsulated content is an objective event, but the predicate confers on the encapsulator the idea of an activity performed because of the Scottish Government's responsibility and commitment towards the citizens ("voters").

(21) $[\ldots]$ quan el catalanisme 1 'hem tancat, el catalanisme no ha avançat. AQUESTA $\varnothing_{i}$ és la

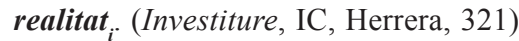

$[\ldots]$ when we have closed Catalanism in itself, Catalanism has not gone ahead. THIS $\varnothing_{i}$ is the reality ${ }_{i}$.

As for (21), the objectivizing evaluation derives mainly from the modal epistemic noun realitat (reality). Moreover, as Catalan is a null-subject language, the copular lexico-grammatical pattern $\left(D E M \varnothing_{i}\right.$ be $\left.N_{i}\right)$ is emphatic: the demonstrative specifier with an elliptical noun occurs in the subject topic position and the encapsulator constitutes the informational contrastive focus (Ribera 2016). Thus, this syntactic configuration contributes to highlighting the addressor's point of view and makes the evaluative function even more explicit (Yamasaki 2008: 80-81).

In sum, evaluative encapsulation is a complex set of strategies which allow the addressors of PDs to highlight their positioning with respect to the diverse subjects of discussion. Objectivizing encapsulation, the preferred evaluative strategy in the three 
languages analyzed, is enhanced not only by the semantic reclassification of subjective ideas; in addition to more or less semantically neutral encapsulators, specifiers, modifiers, predicates and wider syntactic structures which confer objectivity by implying that the whole community works as objectivizing constraint as well.

Objectivizing evaluation is a subtle strategy for appealing to consensus and common sense; thus, although related to the interpersonal metafunction, it highlights the ideational metafunction too, since, by means of this strategy the addressor tries to point out that his or her world view is widely accepted and shared by citizens.

\subsection{Subjectivizing encapsulation as a persuasive strategy}

Subjectivizing encapsulation is an even more explicit evaluative strategy by means of which the addressor confronts openly her or his opponents. As an explicitly subjective procedure for evaluating the PD's topics, it is characterized by exhibiting axiologically marked semantic contents. As in the case of objectivizing encapsulation, the distinction between prototypical and non-prototypical instances has to be established.

\subsubsection{Prototypical subjectivizing encapsulation}

Prototypical subjectivizing encapsulation takes place when an objective fact or event is referred to by means of an overtly subjective encapsulating structure, which evaluates axiologically the encapsulated content from the addressor's viewpoint.

(22) It is clear after the Westminster budget yesterday that the real risk to Scotland comes from remaining as part of the United Kingdom. (Sct P, John Swinney, Cabinet Secretary, SNP, 163)

In (22), the Cabinet Secretary considers that "remaining as part of the United Kingdom" is the real risk; both the definite article, which identifies the referent as unique, and the evaluative premodifier real reinforce the negative subjective perspective on the encapsulated content already shown by the encapsulator risk in this context.

(23) Muchos de ustedes se preguntarán cómo es posible que hoy en el Congreso tengamos algunos el atrevimiento o la osadía de pedir el derecho de voto sobre la independencia de Cataluña. (Congreso, Rovira, Catalan Parliament representative, ERC, 28)

Most of you [politeness] will wonder how it is possible that today in the Congreso some of us have the daring and boldness to request the right to vote on Catalonia's independence.

In (23), the encapsulators atrevimiento (daring) and osadia (boldness) in Spanish refer ironically to the objective event (to request the right to vote on Catalonia's independence). The republican pro-independence representative of the Catalan Parliament adopts her opponents point of view (requesting the right to vote on Catalonia's independence in the Spanish Parliament is daring and bold) to confront them while reinforcing his supporters' point of view. 


\subsubsection{Non-prototypical subjectivizing encapsulation}

There is still a somehow different subjectivizing strategy, which takes place when the encapsulated content is subjective and thus the also subjective encapsulator strengthens the whole discourse chunk's subjectivity. Let's look at some instances.

(24) $[\ldots]$ en l'escenari nacional planta cara, però en l'escenari econòmic el que fa és acatar. I quan vostè es resigna el que fa és, doncs, que el seu conformisme l'acabi pagant la gent, la ciutadania. Quin és el millor actiu per canviar aquesta ambició intermitent? (Investiture, IC, Herrera, 277)

[...] in the national [Catalan] agenda, you face up [to the Spanish government], but, in the economic matters, you obey. And when you resign yourself [to obey], what you do is, therefore, that the people, the citizens, pay for your conformity at last. What is the best asset to change this intermittent ambition?

In (24), Herrera defies the presidential candidate by subjectively considering him ambitious as for the national agenda but not in the economic matters. Both the adjectival premodifier intermitent (intermittent) and the encapsulator ambició (ambition) evaluate ironically and negatively the antecedent; and the text deictic proximal demonstrative aquesta (this) helps make the addressor's stance on the candidate's political activity more present and alive.

(25) What I object to is the rather distorted interpretation of the GERS figures that they somehow show that we are staggeringly wealthy compared with the rest of the UK or that we are particularly hard done by. (Sct P, Ken Macintosh, Lab, 197)

Ken Macintosh's subjective opinion on Scotland's economic wealth in (25) is pointed out by the encapsulating noun phrase: the linguistic noun interpretation refers subjectively to his SNP opponents' words and the premodifier adjectival phrase rather distorted highlights his negative axiological evaluation.

(26) Seguramente al fin de la jornada irán presumiendo de que aquí se acabó todo; que en esta Cámara se ha jugado una final de Champions o de Wimbledon; que estamos asistiendo a un matchball, que quien gane se llevará la copa y quien pierda se irá derrotado para casa, game over. Ese es su discurso. EsE es el festival que ustedes quieren montar hoy aquí; pues, no. (Congreso, Bosch, ERC, Mixed Group, 419)

Certainly, at the end of the session, you [politeness] will boast that everything is finished here; that a final Champions or Wimbledon match has been played in this chamber; that we are attending a matchball, that whoever wins will get the cup and whoever loses will go back home defeated, game over. This is your [politeness] discourse. THIs is the festival that you [politeness] want to hold here today; but no.

The Spanish example in (26) shows the addressor's ironic description of what he assumes subjectively that his opponents will say boastingly after presumably defeating the pro-independence positions in the debate, comparing it to a Champions or Wimbledon final match, with a proud winner and a humiliated loser. This strong defiant description is made even stronger by the whole encapsulating structure with the also ironic noun festival working within the emphatic pattern $D E M \varnothing_{i}$ be $N_{i}$ explained just above in the previous section. Let us look at a final rather different example. 
(27) I jo li vull dir una cosa: no votaré... no votaré i no votaran els nostres dinou diputats a favor de vostè. (Investiture, Sànchez-Camacho, PP, 266)

I would like to tell you [politeness] one thing: I won't vote... won't vote and our nineteen deputies won't vote for your election.

In (27), the subjectivizing strategy derives not from the encapsulator's semantic content, which is, obviously, axiologically neutral. It derives from a pragmatic implicature of the rather fixed construction "li vull dir una cosa" (or "le quiero decir una cosa", in Spanish), which is frequently used in PD both in Catalan and Spanish as an emphatic confrontation strategy. In fact, this idiosyncratic construction in Catalan and Spanish PD seeks for balance between politeness and open confrontation: it tries to face up to the opponents openly; the question is to be well-mannered, at least apparently, in order to avoid damaging one's own image (Cuenca and Marín 2015: 50).

In short, subjectivizing encapsulation exhibits the addressor's ostensive evaluative intent, looking for an overt perlocutive effect. Thus, it shows that evaluative discourse is intrinsically persuasive, at least in the case of PD.

A subjectivizing evaluation seeks to openly confront the opponents and rally the unconditional supporters. Therefore, this strategy contrasts with the objectivizing one, by means of which the addressor tries softening his or her evaluative intentions by appealing to what she or he assumes to be the majority opinion.

Due to the considerable difference in nature between these two evaluative strategies, the addressor should be careful not to overdo the confrontation by means of subjectivizing structures, since they may perform face-threatening acts (Brown and Levinson (1987 [1978]): overuse entails the risk that attacking the opponent may erode the addressor's own image as well.

\section{CONCLUSIONS}

In this paper we have analyzed the role of encapsulation as an evaluative strategy in PD. This cohesive device is characterized by its ability to refer to complex predicative chunks of textual information. It constitutes an essential evaluative tool in this genre of political discourse, as it allows the addressor to guide the addressee's interpretation on the topics discussed.

The semantic classification of the encapsulators unveils similar trends in the three languages analyzed, probably due to the homogenizing power of PD as a genre. However, the debates in English and Catalan show, in decreasing order, more mental, linguistic, modal and factual nouns, whereas modal and factual nouns are more frequent in Spanish than linguistic ones. The higher frequencies of linguistic encapsulators in English and mainly in Catalan show that the debates in these languages are more explicitly structured, at least in our corpus. This fact is derived from the total amount of encapsulators identified in each language, with the highest relative frequency in the Scottish debate and the lowest in the Spanish one.

As for the evaluative operations, the comparisons between the semantic classes of the encapsulated contents and those of the encapsulators are especially meaningful. When semantic identity between the content and the encapsulator takes place, the potential 
for evaluation is less explicit and the mere structuring cohesive operation is underlined. Conversely, when the encapsulator reclassifies the antecedent semantically, the evaluative strength increases. The data obtained from this comparison show certain general crosslinguistic trends: a) the frequencies concerning the reclassifying operations of factual, linguistic and mental contents are lower; b) modal contents are quite lower than modal encapsulators; c) eventive contents are much higher than eventive encapsulators. Thus, generally speaking, many explicit evaluative operations are linked to modal nouns which reconceptualize facts, opinions and events, and to eventive contents reclassified as facts, opinions or simply linguistic activities. However, the diverse evaluative operations do not depend only on the semantic reclassification of the encapsulated contents: several syntactic and discourse-pragmatic constraints work in or on the whole encapsulating structure, so the evaluative strength of specifiers, modifiers, predicates and pragmatic implicatures have to be taken into account as well.

Beyond the general reifying effect of encapsulators, linked to implicit evaluation, this study establishes two different explicit evaluative operations. The objectivizing function evaluates the encapsulated contents subtly and less explicitly, by appealing to common sense and introducing as consensus the retrieved information, whether subjective, prototypically, or already objective. Conversely, the subjectivizing function is semantically marked and more explicit; it highlights the addressor's willingness for confrontation. Thus, objectivizing intends to be more persuasive for the opponents, while subjectivizing seeks to rally and warm up the supporters.

The quantitative results of the analysis of the evaluative functions in our corpus show that the objectivizing operation is the preferred choice in the three languages, followed by the subjectivizing one and/or the general structuring one. PD exhibits an argumentative nature, so it highlights the role of the explicit evaluative encapsulators, well above the basically structuring function. The higher frequencies of the objectivizing evaluation are explained by the addressor's need, in this socio-political and discourse context, to avoid confronting and attacking the opponents openly or harshly, since this could harm her or his own public image.

\section{References}

Borreguero Zuloaga, M. (2006). "Naturaleza y función de los encapsuladores en los textos informativamente densos (la noticia periodística)", Cuadernos de Filología Italiana, 13, pp. 73-95.

Brown, P., \& Levinson, S. C. (1987 [1978]). Politeness: Some Universals in Laguage Usage. Cambridge: Cambridge University Press.

Cuenca, M. J. (2000). “Estudi estilístic i contrastiu de l'arquitectura de l'oració: estil segmentat vs. estil cohesionat", Caplletra, 29, pp. 105-120.

Cuenca, M. J. (2014). "The use of demonstratives and context activation in Catalan parliamentary debate", Discourse Studies, 16, pp. 729-752. DOI: 10.1177/1461445614546258.

Cuenca, M. J., \& Marín, M. J. (2015). "La representación discursiva del adversario en el debate electoral", Oralia, 18, pp. 45-79.

Díez Prados, M., \& Cabrejas Peñuelas, A. B. (2012). "Cohesion in American political rhetoric: The Gettysburg Address, I have a dream and Obama's Inaugural Address", Estudios Ingleses de la Universidad Complutense, 20, pp. 37-60. DOI: 10.5209/rev_EIUC.2012.v20.39994.

Flowerdew, J., \& Forest, R.W. (2015). Signalling Nouns in English: A Corpus-Based Discourse Approach. Cambridge: Cambridge University Press. 
Fuentes Rodríguez, C. (2010). "La aserción parlamentaria: de la modalidad al metadiscurso", Oralia, 13, pp. 97-125.

Geeraerts, D. (2006). Prospects and problems in prototype theory. In D. Geeraerts (ed.) Cognitive Linguistics: Basic Readings. Berlin: Mouton de Gruyter, pp. 141-166 [1989].

Halliday, M. A. K. (1994). An Introduction to Functional Grammar. London: Edward Arnolds.

Halliday, M. A. K., \& Hasan, R. (1976). Cohesion in English, London: Logman.

Hunston, S. (2000). Evaluation and the Planes of Discourse: Status and Value in persuasive texts. In S. Hunston \& Thompson G. (eds.). Evaluation in Text: Authorial Stance and the Construction of Discourse. Oxford: Oxford University Press, pp. 176-207.

Hunston, S. (2008). "The evaluation of status in multi-modal texts", Functions of Language, 15/1, pp. 64-83. DOI: 10.1075/fol.15.1.05hun

Hunston \& G. Thompson (eds.) (2000). Evaluation in Text: Authorial Stance and the Construction of Discourse Oxford: Oxford University Press.

Ilie, C. (2006). Parliamentary discourses. In K. Brown (ed.). Encyclopedia of Language and Linguistics, vol. 9, $2^{\text {a }}$ ed. Oxford: Elsevier, pp. 188-197.

Izquierdo Alegría, D., \& González Ruiz, R. (2013a). "Encapsulación y etiquetas discursivas en el discurso parlamentario: función argumentativa a partir de un corpus paralelo", Oralia, 16, pp. $185-219$.

Izquierdo Alegría, D., \& González Ruiz, R.. (2013b). "La evaluación a través de un mecanismo cohesivo: las etiquetas discursivas en un corpus de editoriales". In C. Llamas Saíz, C. Martínez Pasamar \& M. Casado Velarde (eds.). Léxico y argumentación en el discurso público actual. Frankfurt am Main: Peter Lang, pp.149-185.

Jansen, H. (2003). Densità informativa. Tre parametri linguistico-testuali. Uno studio contrastivo inter- ed intralinguistico. Copenhagen: Museum Tusculanum.

Langacker, R. W. (1987). Foundations of Cognitive Grammar. Theoretical Prerequisites. Stanford: Stanford University Press.

López Samaniego, A. (2014). Las etiquetas discursivas: cohesión anafórica y categorización de entidades del discurso. Pamplona: EUNSA.

Lyons, J. (1977). Semantics II. Cambridge: Cambridge University Press.

Marín, M. J. \& Ribera, J. E (2018). "Estructures encapsuladors amb valor metadiscursiu en el debat parlamentari: De l'estructuració a la modalitat", Caplletra, 64. In Marín, M. J. \& Ribera, J. E. coords, pp. 227-252.

Marín, M. J. \& Ribera, J. E. (coords) (2018). L'encapsulació lèxica: cohesió, coherència i metadiscurs, Caplletra, 64, pp. 105-252.

Mur Dueñas, P. (2003-2004). "Analysing Stance in American and Spanish Business Management RAs: The Case of Sentence-Initial 'Retrospective Labels"”, Journal of English Studies, 4, pp. 137-154.

Ribera, J. E. (2007). "Text Deixis in Narrative Sequences", International Journal of English Studies, 7/1. pp. 149-168.

Ribera, J. E. (2012). La cohesió lèxica en seqüències narratives. Alacant/Barcelona: Institut Interuniversitari de Filologia Valenciana/Publicacions de l'Abadia de Montserrat.

Ribera, J. E. (2016). "Encapsulació i estructura informativa en el debat parlamentari. Una anàlisi contrastiva (català-espanyol-anglès)", Studia Romanica Posnaniensia, 43/2, pp. 29-50. DOI: 10.14746/strop.2016.432.002

Schmid, H. - J. (2000). English Abstract Nouns as Conceptual Shells. From Corpus to Cognition. Berlin: Mouton De Gruyter.

Schmid, H. - J. (2018). "Shell nouns in English - a personal roundup", Caplletra, 64. In Marín, M. J. \& Ribera, J. E. coords., pp. 109-128.

Sentí, A. (2017). Modalitat $i$ evidencialitat en català antic. Un acostament cognitiu a les perifrasis verbals amb deure $i$ amb haver. València/Barcelona: Institut Interuniversitari de Filologia Valenciana/Publicacions de l'Abadia de Montserrat. 
Serafini, M. (1992). Come si scrive. Milano: Fabbri-Bompiani.

Thompson, G., \& Zhou, J. (2000). "Evaluation and Organization in Text: The Structuring Role of Evaluative Disjuncts". In S. Hunston \& G. Thompson (eds.), pp. 121-141.

Van Dijk, T. A. (2000). "Parliamentary Discourse". In R. Wodak \& T. A. Van Dijk (eds.), Racism at the Top. Parliamentary Discourses on Ethnic Issues in Six European States. Klagenfurt: Drava, pp. 45-78.

Yamasaki, N. (2008). "Collocations and colligations associated with discourse functions of unspecific anaphoric nouns", International Journal of Corpus Linguistics 13/1, pp. 75-98. DOI: 10.1075/ ijcl.13.1.05yam. 
